\title{
Model availability of landfill as a conflict mediation process in Central Java
}

\author{
Yulia Pasha ${ }^{1}$, Herdis Herdiansyah ${ }^{1, *}$, Lugina Setyawati ${ }^{2}$, and Elok Faiqotul Mutia ${ }^{1}$ \\ ${ }^{1}$ School of Environmental Science, Universitas Indonesia, Salemba, Indonesia \\ ${ }^{2}$ Sociology Department, Faculty of Social and Political Science, Universitas Indonesia, Depok, \\ Indonesia
}

\begin{abstract}
Waste is still a problem in major cities in Indonesia. The high production of waste is not proportional to the availability of the landfill (TPA). The land use plans for waste landfill by local governments have conflict potential between government and community when such infrastructure facilities are not desired by the community. Environmental conflicts/disputes can be resolved through mediation mechanisms. This research uses linear regression modeling system to see the correlation between the amount of waste volume generated with the availability of landfill (TPA) in Central Java Province. The results showed the greater the number of residents the greater the volume of waste generated. In contrast the number of available landfill (TPA) is not affected by the volume of waste because the regression coefficient is only 0.0256 .
\end{abstract}

\section{Introduction}

Indonesia has the fourth largest population in the world after China, India, and the United States [1]. The total population of Indonesia in 2025 is projected to rise to 284.83 million from 238.52 million in 2010. This number will continue to grow to 305.65 million by 2035 . BPS is also projected by 2030 more than $60 \%$ of the population Indonesia lives in urban areas. Population growth is followed by increasing demand for land, so the correlation entails the larger the number of people, the less amount of land available.

Human activities and lifestyles always produce unused waste and pollute the environment [2]. Increasing the amount of household waste generated is positively correlated with the number of population, i.e. the larger the number of people in a region, the more the amount of household waste produced [1]. Provinces in Indonesia with the largest population in 2016 are sequentially occupied by West Java, East Java, and Central Java [1].

Garbage and its management are still a problem in major cities in Indonesia $[1,3]$. Data from the Ministry of Environment mentioned that in 1995 the average person in urban areas in Indonesia produced 0.8 kilograms of garbage per day and continued to increase up to 1 kilogram per person per day in 2000. Estimated waste pile in 2020 for each person per day is 2.1 kilograms, so with an ever-increasing number of residents it is estimated that the

* Corresponding author: herdis@ui.ac.id 
waste produced per day is about 500 million kilograms by 2020 or about 190,000 tons per year [3].

Production of solid waste per day is quite high in Java, namely in Jakarta, Surabaya, and Semarang [1]. The high production of waste is not proportional to the availability of land and the number of landfill (TPA) available. Data from the Ministry of Public Works and Public Housing or Kementrian Pekerjaan Umum dan Perumahan Rakyat (PU-PR) in 2015, said that Central Java Province has only 3 (three) landfill (TPA) with a land area of 15.50 hectares and a capacity of 175 cubic meters. Limited land in big cities become one of the causes of waste accumulation increases. The same thing happened in Klaten District in Central Java Province.

Data from the Public Works and Spatial Planning Office of Klaten Regency in 2016 stated that Klaten Regency has 1 landfill (TPA) which is Candirejo TPA with a land area of 0.9 hectares, and 224 local transfer station (TPS) which are 207 permanent models and 17 containers. The collection and transportation of garbage is done once a day. The amount of waste production generated by the people of Klaten Regency reaches 255.4 cubic meters per day, resulting in waste generation of 896 cubic meters per day, with garbage transported from local transfer station (TPS) to landfill (TPA) of 162 cubic meters per day or $18.08 \%$. The Government of Klaten Regency allocates a total of IDR 5.050.000.000,00 (over 5 billion rupiahs) of garbage into TPAS by 2016.

The need for a landfill (TPA) encourages the District Government of Klaten to build a landfill (TPA) in Troketan Village Pedan District with a planned land area of 9,464 hectares. The plan of the Troketon TPA will start operating in 2018, but this is facing challenges with the rejection of the local community in 3 (three) villages in Pedan subdistrict ie Kaligawe Village, Troketon Village, and Kalangan Village. The rejection of the local community resulted in conflict between the Government of Klaten district and the community. Environmental dispute can be resolved through Alternative Dispute Resolution mechanism [4]. The most common form of Alternative Dispute Resolution is mediation [5].

\section{Literature review}

Waste is produced from materials that are not used in human activities and pollute the environment. Waste or solid waste, divided into two types: industrial solid waste generated by mines, farms, and industries that supply goods and services to people; and municipal solid waste is a mixture of solid waste produced by houses and offices other than factories, for example paper, cardboard, food scraps, cans, bottles, yard waste, plastics, metal, glass, and electronic waste $[2,6]$.

Solid waste can be managed by 2 (two) approaches: waste management and waste reduction [2]. Waste management is trying to reduce the environmental impact of urban solid waste without reducing the amount of waste generated. The second way is to reduce waste, which produces less waste and less pollution, and the waste generated is considered a potential resource that can be reused, recycled or composted.

The need for effective solid waste management becomes an environmental management strategy in Indonesia [7] especially since the issuance of Law No. 18 of 2008 on Waste Management (hereinafter referred to as Law 18/2008) of Law 18/2008. Referring to this law, waste management is a systematic, thorough, and continuous activity that includes waste reduction and handling. It is estimated that only about $2 \%$ of the provinces in Indonesia are budgeted for waste management [7].

The definition of landfill according to the $18 / 2018$ Act is a place to process and return the waste to environmental media safely for humans and the environment. The waste and the residue of its processing are returned to the environmentally safe medium preceded by processing to change the characteristics, composition and amount / volume of waste [8]. To 
date there are 4 (four) types) of landfill (TPA) operated in Indonesia, namely open dumping, controlled, sanitary, and modern sanitary [7]. The type of infrastructure development where the landfill (TPA) is best known is open dumping, which results in environmental pollution. This has led to a decline in the quality of urban environments including ground water [7].

The construction of public infrastructure facilities such as substations, landfills, incinerators, power plants, roads, and hospitals [9], often face challenges from local communities when specific locations are submitted [10]. Land use planning or local land use in the site selection process is undesirable by local communities and potentially conflict [11]. The understanding of society is based on the fact that certain facilities will create negative externalities or disturbances that will affect the surrounding environment in the presence of development, but have no significant impact on people and houses around the site [12].

Conflict is caused by differences of perspective or point of view due to differences in economic, social, cultural, background, and values $[13,14]$. These differences lead to disagreement so that conflict occurs [13]. This can be between two parties individually, communal, or even involving many parties and States [14]. Conflict over a policy is characterized by limited information that are obtained by the community and uncertainty about the process [15]. Mediation can be used in resolving environmental disputes since it is very effective that involve multiple parties or communities for an environmental destruction [16]. In some developed countries such as Japan, the United States, and Canada, environmental dispute resolution places greater emphasis on the use of mediation [17].

\section{Material and method}

Linear regression is used to analyze the relationship (correlation) between dependent and independent variables based on data provided from the statistical point of view that is random observation data with some size errors. On the other hand, the relationship between dependent and independent variables can be characterized by an unclear functional relationship for unclear data [18].

This research uses linear regression to see the validity level of the model in predicting the number of landfill needed to accommodate the volume of waste, to see the correlation between the number of residents with the volume of waste, and the correlation between the volume of waste with the amount of landfill availability. The linear regression model [19] uses calculations:

$$
y=X \beta+\varepsilon
$$

i.e. $y$ shows the observation vector of the dependent variable, $X$ denotes the independent variable and the design matrix of the regression model, $\beta$ denotes the vector of unknown regression parameters, and $\varepsilon$ is the interference vector.

\section{Results and discussion}

The linear regression model to see the correlation between the number of population and the volume of waste, and the correlation between the volume of waste with the number of available landfill (TPA) is done through the collection of population data, the volume of waste, and the number of available TPA. Population data in Central Java Province taken from 2010 to 2014 can be seen in Table 1 . 
Table 1. Population in Central Java Province 2010 to 2014 adapted from Purba et al (2017).

\begin{tabular}{|c|c|c|c|}
\hline \multirow{2}{*}{ Year } & \multicolumn{3}{|c|}{ Gender (people) } \\
\cline { 2 - 4 } & Male & Female & Total \\
\hline 2010 & 16.091 .555 & 163.52 .331 & 32.443 .886 \\
\hline 2011 & 16.231 .847 & 16.493 .531 & 32.725 .378 \\
\hline 2012 & 16.367 .703 & 16.630 .989 & 32.998 .692 \\
\hline 2013 & 16.499 .377 & 16.764 .962 & 33.264 .339 \\
\hline 2014 & 16.627 .023 & 16.895 .640 & 33.522 .663 \\
\hline
\end{tabular}

Data on the volume of waste per day and the number of TPA available in Central Java Province is shown in Table 2.

Table 2. Waste volume per day in Central Java Province 2010 to 2014 adapted from Department of Public Works of Regency/City throughout Central Java Province (2014).

\begin{tabular}{|c|c|c|}
\hline Year & Waste Volume & Number of Landfill (TPA) \\
\hline 2010 & $737.168,68$ & 65 \\
\hline 2011 & $24.116,63$ & 57 \\
\hline 2012 & $29.466,47$ & 61 \\
\hline 2013 & $33.337,51$ & 59 \\
\hline 2014 & $34.278,41$ & 63 \\
\hline
\end{tabular}

The result of simulation of correlation between population and waste volume is shown in Figure 1. The simulation is done to predict the volume of waste generated by the population and see the correlation between the variable $X$ (horizontal axis) that is the population with the variable Y (vertical axis) i.e. the volume of waste. Positive correlation $(+)$ occurs if the larger the population, the greater the volume of waste. Negative correlation $(-)$ if the smaller the population the smaller the volume of waste. The correlation between the variables in Figure 1 shows the model in the mathematical equation (formula) is $\mathrm{Y}=$ $0.5254 \mathrm{X}+2 \varepsilon+07$ with the determinant coefficient is $\mathrm{R}^{2}=0.5022$ indicating the validation rate. The model prediction on 2010 can be calculated if the variable Y known as 737.168,68 waste volume then variable $\mathrm{X}$ which is the number of people can be calculated or vice versa. Validation results show there is correlation or influence between the population with the volume of garbage though not dominant. The bigger the population, the greater the volume of waste generated. 


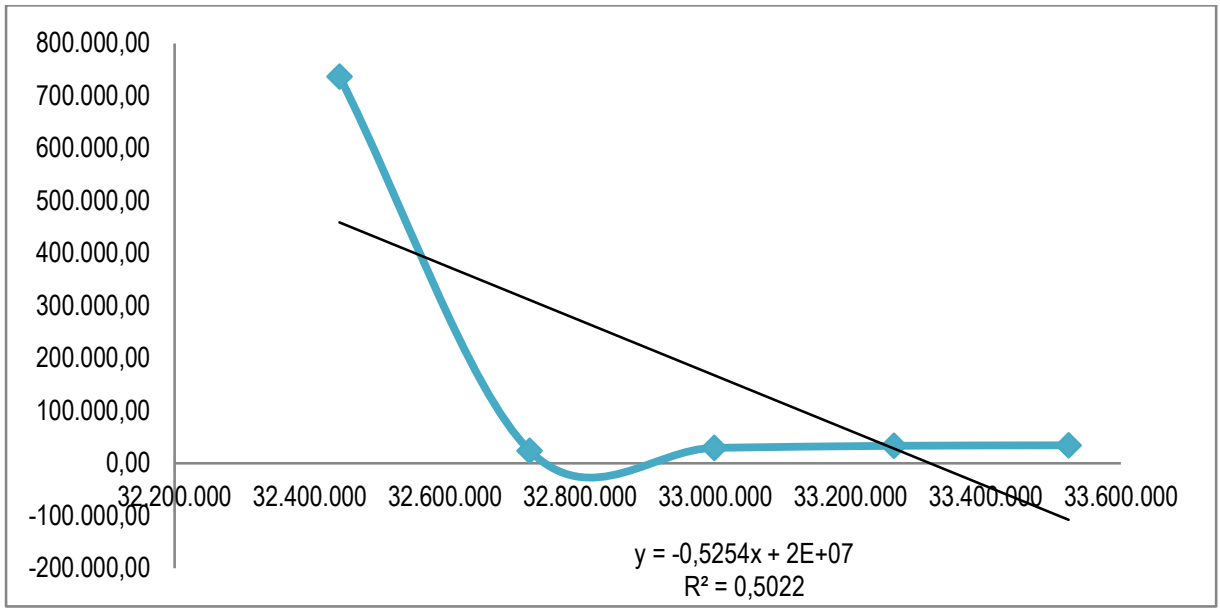

Fig. 1. Linear regression model of population and volume of garbage.

Result of the simulation of correlation between garbage volume with the number of TPA is shown in Figure 2. Simulation is done to predict the amount of TPA needed with the volume of waste generated by the population and see the correlation between variable $\mathrm{X}$ (horizontal axis) that is the volume of waste with variable $y$ is the number of TPA. Figure 2 shows the model in the mathematical equation (formula) is $\mathrm{y}=-1 \varepsilon-05 \mathrm{X}+75,443$ with the determinant coefficient is $\mathrm{R}^{2}=0.0256$ indicating the model validation rate. Validation results show no correlation between the volume of waste with the number of landfill available. Greater volume of waste does not affect the number of available TPA.

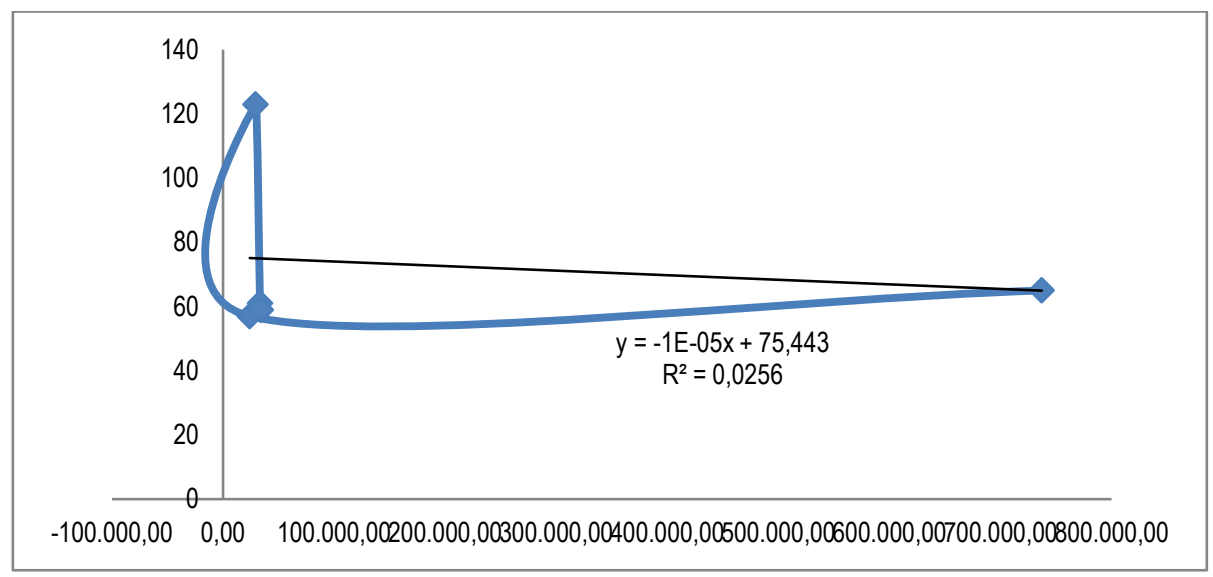

Fig. 2. Linear regression model of waste volume and number of landfill.

Land use planning for waste landfill affects the number of waste landfill availability in Klaten. The location or site of waste landfill has been regulated in local regulation Number 13 year 2012 on Waste Management. The availability policies are often in conflict with others and it can be analyzed using a qualitative approach [20]. Land use for waste landfill has potential conflict as being opposed by local community. The most common form of conflict resolution or environmental dispute is mediation. In some places, the potential of waste can be used as alternative energy [22], as well as urban waste management is now beginning to be done with community engagement approach, hope the empowerment approach will reduce the potential for future conflicts [23], including involving women in the movement of sorting and choosing waste from household [24] [25] 


\section{Conclusion}

The results showed the coefficient is 0.502 . It means that the ability of the independent variable explained by the variant of the dependent variable is $50,2 \%$ and the variant of the dependent variable explained by other factors is $49,8 \%(100 \%-50,2 \%)$. The coefficient denotes that there was a correlation or influence between the population with the volume of garbage though it is not dominant. This shows the greater the population, the greater the volume of waste generated. In contrast the number of available waste landfill is not affected by the volume of waste because the regression coefficient is only 0.0256 or $25,6 \%$. It means that the variant of the dependent variable explained by other factors was bigger than the ability of the independent variable explained by the variant of the dependent variable that is $74,4 \%(100 \%-25,6 \%)$.

The land use plans for waste landfill by local governments have conflict potential between government and community when such infrastructure facilities are not desired by the community. The waste landfill conflict can be categorized as an environmental conflict/dispute which can be resolved through mediation mechanisms.

\section{Acknowledgment}

This research is funded by the Grant of Indexed International Publication for Final Project of Students/Publikasi Terindeks Internasional Untuk Tugas Akhir Mahasiswa (PITTA) Universitas Indonesia 2018 with contract number 2579/UN.R3.1/HKP.05.00/2018.

\section{Reference}

1. Purba, W. Sartika, Safitri, P. Ajeng, R. Andianti. Indonesia environmental statistics 2017 (Indonesian Central Bureau of Statistics, Jakarta, 2017)

2. G.T. Miller, S.E. Spoolman. Sustaining the earth (10th ed) (Belmont, Brooks/Cole., 2012a)

3. M. Suparmoko. Ekonomi sumber daya alam dan lingkungan: Suatu Pendekatan Teoritis (Edisi 4 Revisi) (Fakultas Ekonomika dan Bisnis UGM, Yogyakarta, 2016)

4. H. Rhiti. Panduan lengkap hukum penyelesaian sengketa lingkungan hidup: untuk mahasiswa, umum, dan penegak hukum (Universitas Atma Jaya, Yogyakarta, 2013)

5. S. Matsumoto. A duration analysis of environmental alternative dispute resolution in Japan. Journal of Ecological Economics 70, (2011)

6. G.T. Miller, S.E. Spoolman. Living in the environment (17th ed) (Belmont: Brooks/Cole, 2012b)

7. Ministry of Energy and Mineral Resources. Waste to energy guidebook (Directorate General of New, Renewable Energy and Energy Conservation Ministry of Energy and Mineral Resources, Jakarta, 2015)

8. Kementerian Pekerjaan Umum dan Perumahan Rakyat. Informasi Statistik Infrastruktur (Pusat Data dan Informasi Kementerian PUPR, Jakarta, 2015)

9. L. Sun, E.H.K. Yung, E.H.W. Chan, D. Zhu. Issues of NIMBY conflict management from the perspective of stakeholders: a case study in Shanghai. Journal of Habitat International 53, (2015)

10. P.J. Davidson, M. Howe. Beyond NIMBYism: understanding community antipathy toward needle distribution services. Journal of International Journal of Drug Policy, (2013) 
11. I.A. Kaya, N.K. Erol. Conflicts over Locally Unwanted Land Uses (LULUs): reasons and solutions for case studies in Izmir (Turkey). Journal of Land Use Policy 58, (2016)

12. P. Hubbard. NIMBY. Journal of Elsevier, (2009)

13. S. Fisher, J. Ludin, S. Williams, D.I. Abdi, R. Smith, S. Williams. Mengelola konflik. translated from working with conflict: skills and strategies for action (Karikasari, S.N., Tapilatu, Meiske D., Maharani, Rita, dan Rini, Dwiati Novita, Penerjemah) (The British Council, Jakarta, Indonesia, 2001)

14. C. Irawan. Aspek hukum dan mekanisme penyelesaian sengketa di luar pengadilan (Alternative Dispute Resolution) di Indonesia. (Mandar Maju, Bandung, 2010)

15. A. Dagnino, N.M. Fraser, K.W. Hipel. Conflict analysis of an environmental dispute. Journal of Negotiations and Conflict Resolutions, (1985)

16. Sudiarto. Negosiasi, mediasi, dan arbitrase: penyelesaian sengketa alternatif di Indonesia. (Pustaka Reka Cipta, Bandung, 2015)

17. S. Sunarso. Hukum Pidana Lingkungan Hidup dan Strategi Penyelesaian Sengketa (Rineka Cipta, Jakarta, 2005)

18. P. Guo, H. Tanaka. Dual models for possibilistic regression analysis. Journal of Computational Statistics \& Data Analysis 51, (2006)

19. M. Cerny, J. Antoch, M. Hladík, Milan. On the possibilistic approach to linear regression modelsinvolving uncertain, indeterminate or interval data. Journal of Information Sciences 244, (2013)

20. T. Tryfonas, D. Gritzalis, S. Kokolakis. A qualitative approach to information availability. Journal of Information Security for Global Information Infrastructures, (2000)

21. Central Java Province of Central Bureau of Statistics. Environmental Data and Information in Central Java 2014. (Central Java Province of Central Bureau of Statistics, Semarang, 2014)

22. Nuryadin, Tb R.R.Nitibaskara, H. Herdiansyah, R. Sari. The model of gas supply capacity simulation in regional energy security framework: policy studies PT. X Cirebon Area. IOP Conference Series: Earth and Environmental Science 88012029, (2017)

23. A. Brotosusilo, D. Utari, A.A. Satria. Sustainability of water resources in the upstream watershed-based community engagement and multistakeholder Cooperation. IOP Conference Series: Earth and Environmental Science 30 012018, (2016)

24. D. Asteria, H. Herdiansyah, I.W.A. Apriana. Women's Environmental Literacy as Social Capital in Environmental Management for Environmental Security of Urban Area. IOP Conference Series: Earth and Environmental Science 30 012014, (2016)

25. D Asteria, Budidarmono, H. Herdiansyah, N.L. Ni'mah. Gender sensitive education in watershed management to support environmental friendly city. IOP Conference Series: Earth and Environmental Science 126 012146, (2018) 